\title{
Prenatal and postnatal factors related to the incidence of stunting in the coastal area Surabaya, Indonesia
}

\author{
*Ilya Krisnana ${ }^{1}$, Ni Made Widiani², Sulistiawati Sulistiawati ${ }^{2}$
}

Sri Lanka Journal of Child Health, 2020: 49(3): 223-229

\begin{abstract}
Objectives: To assess the prenatal and postnatal factors associated with the incidence of stunting in 6-24 month old children in the coastal area Surabaya, Indonesia.
\end{abstract}

Design: Observational cross-sectional study.

Method: Total sample of 100 included mothers and 6-24 month old children fulfilling the inclusion criteria. Multistage random sampling was used. Collected data underwent bivariate and multivariate analyses. Odds ratio (OR) and risk ratio (RR) were two commonly used measures of association reported in research studies. In cross-sectional studies, the odds ratio was also referred to as the prevalence odds ratio (POR) when prevalent cases are included, and, instead of the RR, the prevalence ratio (PR) was calculated.

Results: Stunting incidence was associated with anaemia in the second trimester of pregnancy $(p=0.002, \quad P R=3.244), \quad$ history of exclusive breastfeeding $(\mathrm{p}=0.003, \mathrm{PR}=3.938)$, and history of maternal iron consumption during pregnancy $(p=0.006, P R=3.798)$.

Conclusions: Prenatal factors such as anaemia and iron consumption during pregnancy were associated with stunting. Exclusive breastfeeding was the only postnatal factor that was associated with stunting. Infants who were given exclusive breast milk had a 3.98 times lower risk of stunting compared to babies who did not get exclusive breast milk.

DOI: http://dx.doi.org/10.4038/sljch.v49i3.9138

${ }^{1}$ Faculty of Nursing, ${ }^{2}$ Faculty of Medicine,
Universitas Airlangga,Indonesia
*Correspondence: ilya-k@fkp.unair.ac.id
iD) orcid.org/ 0000-0001-8076-9036

(Received on 06 September 2019: Accepted after revision on 18 October 2019)

The authors declare that there are no conflicts of interest

Personal funding was used for the project.

Open Access Article published under the Creative

Commons Attribution CC-BY (CC) (1) License
(Keywords: Stunting, pregnancy history, infant history, coastal area, iron consumption, exclusive breastfeeding)

\section{Introduction}

Malnutrition associated with stunting is a significant problem ${ }^{1}$. One factor causing stunting is long-term malnutrition occurring during the first 1000 days of birth from the beginning of conception to 2 years of age $^{2}$. Risk factors for stunting are prenatal and postnatal. Prenatal factors play an important role in preventing stunting and have a long impact on a child's growth ${ }^{3,4}$. Other factors include getting complete vaccination, lack of maternal education ${ }^{5}$, late initiation of breastfeeding, and having an infectious disease ${ }^{6}$. Poor sanitation, poverty, social inequality, and food insecurity have also become factors causing stunting?

According to World Health Organisation (WHO) standards, stunting is a public health problem if its prevalence in the under-5 year old children exceeds $20 \%$. Globally, stunting incidence of under-5 year old children reached one million, which was around $22 \%$, in $2017^{8}$. In the Southeast Asia region, onethird of children have stunting and malnutrition ${ }^{1}$. The number of stunting events in Indonesia is $29.6 \%{ }^{2}$. Basic Health Research in 2013 showed that $25 \%$ of children under five in Indonesia experienced stunting from birth, at the age of 0-5 months, which showed that the child had experienced malnutrition from the intrauterine period ${ }^{9}$. Based on Nutritional Status Monitoring, the Directorate of Community Nutrition reported the percentage of stunting in East Java Province was $26.7 \%$ in $2017^{10}$. The percentage of children under five experiencing stunting in Surabaya was $22.8 \%$ in $2017^{2}$. Stunting prevalence in a toddler in Tanah Kedinding Health Centre in Kenjeran District was $25.7 \%$ in $2014^{11}$.

Maternal nutritional status during first 1000 days of life from conception, is one of the risk factors for stunting. Second trimester of pregnancy anaemia affects the baby's postnatal growth. Infants whose mothers are not anaemic in the second trimester are heavier, and have greater body length and head circumference ${ }^{12}$. Taking iron tablets weekly during pregnancy is related to an increase in the weight and length of the neonate. Adequate weight gain in pregnancy also contributes to weight and length of the neonate ${ }^{13}$. Longitudinal research results showed that low birth weight infants cannot experience 
height recovery in the first year even if the baby was in a more prosperous family ${ }^{14}$. Giving breast milk also affects the postnatal growth of the baby. The components of protein and fat in breast milk affect the growth of a baby's length ${ }^{15}$. Stunted children have a much higher risk of experiencing long-term health problems than those without stunting ${ }^{16}$. Stunting also contributes to child mortality, morbidity, and disability, including impaired physical and cognitive growth.

\section{Objectives}

To assess the prenatal and postnatal factors associated with the incidence of stunting in 6-24 month old children in the coastal area Surabaya, Indonesia.

\section{Method}

This was a cross-sectional study. The study population consisted of children aged 6-24 months and multistage random sampling technique was used. The population areas used for the study were health centres and posyandu (integrated service post). Randomization was carried out at the community health centre level so that three health centres were obtained. Then randomization was carried out at the posyandu level, located in the three health centres, to get 10 posyandu. Each posyandu was taken with a sample of 10 samples each with inclusion criteria, namely having a complete maternal and child health $(\mathrm{MCH})$ book (there were data on body weight during pregnancy, height, weight at the end of pregnancy, haemoglobin levels in second trimester of pregnancy, iron tablet consumption, baby's birth weight and length). The research instrument used was a data collection sheet. Collected data included personal information, antenatal history, baby's anthropometry and baby's dietary history.

Data collection: Based on data obtained from the community health centre, randomization was done and 10 posyandu were selected. Researchers were introduced to posyandu cadres by primary health centre officers. Researcher approaches the respondent from the cadres, who connect with the respondent so that the sample was obtained. Prospective respondents were determined by taking 10 samples that meet the inclusion criteria in each selected Posyandu. Researcher explained the purpose, benefits, participation of respondents, and guarantees confidentiality of the respondents. Respondents signed the approval sheet, then data collection was carried out. Nutritional status data based on length/age were taken by measuring body length using a length board in toddler who cannot stand and microtoise on children who can stand. Data on body weight before pregnancy and breastfeeding history were taken through interviews. Data on pregnancy weight gain, anaemia in second trimester of pregnancy, and consumption of iron tablets during pregnancy, infant birth weight and length were taken from medical records in the form MCH books.

Data analysis: In this study data was analysed using a univariate analysis test which was used to describe the frequency distribution of subject characteristics and characteristics of respondents. Bivariate analysis was used to determine the relationship between the dependent and independent variables, the statistical test used was Chi-square. Multivariate analysis was used to determine how much the independent variables affects the dependent variable and the statistical test used was multiple logistic regression $(\alpha=0.05)$. Odds ratio (OR) and risk ratio (RR) are two commonly used measures of association reported in research studies. In crosssectional studies, the odds ratio is also referred to as the prevalence odds ratio (POR) when prevalent cases are included, and, instead of the RR, the prevalence ratio $(\mathrm{PR})$ is calculated.

Ethical issues: All respondents in this study received an explanation before signing an informed consent form. Ethical clearance was obtained from the health research ethics committee of the Faculty of Medicine, Universitas Airlangga, Surabaya, with certificate no. 5/EC/KEPK/FKUA/2019.

\section{Results}

The characteristics of the children are shown in Table 1 and the characteristics of the mothers in Table 2.

Table 1: Children' characteristics $(n=100)$

\begin{tabular}{|l|c|}
\hline \multicolumn{1}{|c|}{ Characteristic } & Number (\%) \\
\hline Sex & $60(60)$ \\
Male & $40(40)$ \\
Female & \\
\hline Age (months) & $44(44)$ \\
$6-12$ & $43(43)$ \\
$13-18$ & $13(13)$ \\
$19-24$ & \\
\hline
\end{tabular}

Table 2: Mothers' characteristics $(n=100)$

\begin{tabular}{|l|c|}
\hline \multicolumn{1}{|c|}{ Characteristic } & Number (\%) \\
\hline Age (years) & $01(01)$ \\
$<20$ & $86(86)$ \\
$20-35$ & $13(13)$ \\
$>35$ & \\
\hline Education & $12(12)$ \\
Elementary school & $27(27)$ \\
Junior high school & $44(44)$ \\
Senior high school & $17(17)$ \\
College & \\
\hline Job & $22(22)$ \\
Employee & $02(02)$ \\
Entrepreneur & $76(76)$ \\
Does not work & \\
\hline
\end{tabular}


Incidence of stunting was $28 \%$. Analysis of factors associated with the incidence of stunting in children in coastal area Surabaya, Indonesia, is shown in Table 3.

Table 3: Analysis factors incidence of stunting on children in coastal area Surabaya Indonesia

\begin{tabular}{|c|c|c|c|c|c|}
\hline \multirow[t]{2}{*}{ Independent variable } & \multicolumn{2}{|c|}{ Incidence of Stunting $(n=28)$} & \multirow{2}{*}{$\begin{array}{l}\text { Total } \\
\text { n (\%) }\end{array}$} & \multirow[t]{2}{*}{ p value } & \multirow[t]{2}{*}{ PR } \\
\hline & $\begin{array}{c}\text { Stunting } \\
\text { n (\%) }\end{array}$ & $\begin{array}{c}\text { No stunting } \\
\text { n }(\%)\end{array}$ & & & \\
\hline $\begin{array}{l}\text { History of maternal iron consumption } \\
\text { As recommended } \\
\text { Not as recommended }\end{array}$ & $\begin{array}{l}10(16.9) \\
18(43.9)\end{array}$ & $\begin{array}{l}49(83.1) \\
23(56.1)\end{array}$ & $\begin{array}{l}59(100) \\
41(100)\end{array}$ & 0.006 & 3.789 \\
\hline $\begin{array}{l}\text { History of anaemia } \\
\text { No anaemia } \\
\text { Anaemia }\end{array}$ & $\begin{array}{l}12(17.6) \\
16(50.0)\end{array}$ & $\begin{array}{l}56(82.4) \\
16(50.0)\end{array}$ & $\begin{array}{l}68(100) \\
32(100)\end{array}$ & 0.002 & 3.244 \\
\hline $\begin{array}{l}\text { Gestational weight gain } \\
\text { As recommended } \\
\text { Not as recommended }\end{array}$ & $\begin{array}{l}09(23.7) \\
19(30.6)\end{array}$ & $\begin{array}{l}29(76.3) \\
43(69.4)\end{array}$ & $\begin{array}{l}38(100) \\
62(100)\end{array}$ & 0.601 & - \\
\hline $\begin{array}{l}\text { Birth weight } \\
\text { Normal } \\
\text { Low birth weight } \\
\text { Very low birth weight }\end{array}$ & $\begin{array}{c}28(28.6) \\
0(0) \\
0(0)\end{array}$ & $\begin{array}{l}70(71.4) \\
01(100) \\
01(100)\end{array}$ & $\begin{array}{l}98(100) \\
01(100) \\
01(100)\end{array}$ & 0.794 & - \\
\hline $\begin{array}{l}\text { Birth length } \\
\text { Normal } \\
\text { Abnormal }\end{array}$ & $\begin{array}{l}25(26.9) \\
03(42.9)\end{array}$ & $\begin{array}{l}68(73.1) \\
04(57.1)\end{array}$ & $\begin{array}{l}93(100) \\
07(100)\end{array}$ & 0.396 & - \\
\hline $\begin{array}{l}\text { History of breastfeeding } \\
\text { Exclusive breastfeeding } \\
\text { Not exclusive breastfeeding }\end{array}$ & $\begin{array}{l}10(16.4) \\
18(46.2)\end{array}$ & $\begin{array}{l}51(83.6) \\
21(53.8)\end{array}$ & $\begin{array}{l}61(100) \\
39(100)\end{array}$ & 0.003 & 3.938 \\
\hline
\end{tabular}

PR: Prevalence ratio

Based on table 3 , there is an association between anaemia history in the second trimester of pregnancy and the incidence of stunting $(\mathrm{p}=0.002, \mathrm{PR}=3.244)$ in children. This means that a child whose mother has anaemia in the second trimester of pregnancy has 3.244 more chance of experiencing stunting than a child whose mother does not have anaemia in second trimester. There is an association between breastfeeding history and the incidence of stunting $(\mathrm{p}=0.003, \mathrm{PR}=3.938)$ in children. This means that children who were not given exclusive breastfeeding have a 3.938 greater chance to experience stunting than those who were given exclusive breastfeeding. There is also a relationship between the history of maternal iron consumption during pregnancy and the incidence of stunting $(\mathrm{p}=0.006, \mathrm{PR}=3.798)$ in children. This means that children whose mothers did not take iron tablets as recommended during pregnancy have a 3.798 greater chance to experience stunting than those who received iron tablets as recommended.

The results of multivariate analysis with multiple logistic regression test are shown in Table 4.

Table 4: The results of multivariate analysis with multiple logistic regression test

\begin{tabular}{|l|c|c|c|c|c|}
\hline \multicolumn{1}{|c|}{ Variable } & \multirow{2}{*}{ B } & \multirow{2}{*}{ P value } & \multirow{2}{*}{ Exp (B) } & \multicolumn{2}{c|}{ 95\% CI for EXP (B) } \\
\cline { 5 - 6 } & & & Lower & Upper \\
\hline $\begin{array}{l}\text { History of anaemia during second trimester } \\
\text { of pregnancy }\end{array}$ & 1.449 & 0.005 & 4.258 & 1.543 & 11.754 \\
\hline History of breastfeeding & & & & & \\
\hline History of maternal iron consumption & 1.323 & 0.010 & 3.753 & 1.370 & 10.277 \\
\hline
\end{tabular}

Table 4 shows that history of anaemia during the second trimester of pregnancy can significantly affect the incidence of stunting $(p=0.005, p<0.01)$. The table also shows the Exp (B) value of 4.258, which means that one whose mother has anaemia in the second trimester of pregnancy has the chance to experience a stunting incidence of 4.258 more than the one whose mother has no anaemia in the second trimester of pregnancy. Table 4 shows that the history of breastfeeding can significantly affect the incidence of stunting $(p=0.010, p<0.05)$. The table also shows the $\operatorname{Exp}(\mathrm{B})$ value of 3.753 , which means that toddlers who were not given exclusive breastfeeding had a chance to experience a stunting incidence of 3.753 greater than those who were given exclusive breastfeeding. Table 4 also shows that the history of consumption of maternal iron during pregnancy can significantly affect the incidence of stunting $(p=0.018, p<0.05)$. The table also shows the $\operatorname{Exp}(\mathrm{B})$ value of 3.399 which means that the number of mothers whose mothers did not take iron tablet as recommended during pregnancy 
had a chance to experience a stunting incidence of 3.399 greater than those who received iron tablet as recommended.

\section{Discussion}

Pregnant women have an increased risk of anaemia due to changes in blood plasma volume and the amount of iron consumed in a meal is not sufficient, so an additional iron tablet is needed to prevent the effects of anaemia during pregnancy ${ }^{17}$. Our study demonstrated a significant association between the history of iron consumption during pregnancy and the incidence of stunting in children. A previous study in Nepal also showed a relationship between iron consumption during pregnancy and incidence of stunting, where children, whose mothers consumed iron during pregnancy, were taller than children whose mothers did not consume iron during pregnancy $^{18}$.

Pregnant women need more iron and so they have to get additional iron supplements. However, if a woman becomes pregnant with decreased iron reserves, iron supplementation frequently fails to prevent iron deficiency ${ }^{19}$. Though iron absorption greatly increases after 20 weeks of gestation, the effect of decreasing fetal growth from iron deficiency in the first trimester persists in spite of subsequent iron supplementation ${ }^{20}$. Weight gain during pregnancy increases due to the fetus, amniotic fluid, placenta, blood, enlargement of the uterus and breast.

Anaemia has an impact on the mother and fetus. In our study, history of anaemia in the second trimester was significantly associated with stunting incidence in child. This is similar to a previous study where there was an association of anaemia during pregnancy with stunting incidence in child ${ }^{21}$. A cohort study in India demonstrated that anaemia in second trimester affected postnatal growth of infants, where mothers who did not have anaemia in second trimester had babies who were longer and heavier than infants whose mothers had anaemia in second trimester ${ }^{12}$. A smaller decrease in haemoglobin levels from the beginning of pregnancy can be an indication of a failure to increase plasma volume during pregnancy, which can disrupt feto-placental circulation ${ }^{22}$. Disrupted placental flow is also related to maternal vascular dysfunction which may be involved in obstructing fetal growth ${ }^{23}$. The fetal linear growth rate peaks at about 16 weeks of pregnancy, followed by a decrease ${ }^{24}$. Besides, ultrasound measurements of growth velocity for the length of femur in a healthy fetus indicate that peak growth rate occurs in early second trimester followed by gradual decline in third trimester ${ }^{25}$. In our study, maternal anaemia during the second trimester may have had a significant effect on fetal linear growth.
Total body weight depends on the mother's weight before pregnancy ${ }^{26}$. Previous research conducted in Bogor showed no relationship between maternal weight gain in pregnancy and the baby's length ${ }^{27}$. Weight gain in each trimester of pregnancy was significantly positively related to infant growth. This is supported by previous studies that showed that weight gain in pregnancy affects length of the baby $^{28}$. Research conducted in New York shows that increasing body weight each trimester has an important role in infant growth ${ }^{29}$. In our study, there was no specific categorization of maternal weight gain per trimester. Other research also mentions that babies with excessive maternal weight gain during pregnancy experience slower growth in the first year of life, compared to infants whose maternal weight gain during pregnancy is recommended ${ }^{30}$. In our study, body length of the baby was not examined every month and so it is not known whether or not in the person experiencing growth slowdown the mother's weight gain during pregnancy was appropriate or not.

Neufeld, et al. (2004) states that even though maternal weight gain during pregnancy can be used to predict the length of the baby, it is not significantly associated with the growth of the infant femur or tibia ${ }^{24}$. Besides, the gestational period is very sensitive to fetal growth. Factors related to and contributing to the growth of infants are considered to be multidimensional, for example, iron tablet supplementation, and tetanus toxoid immunization while still in the womb, maternal disease, drug treatment, alcohol, drug addiction, and smoking ${ }^{31}$. Infant birth weight is an important parameter for assessing the health and well-being of a newborn baby. Our study showed no significant relationship between the histories of birth weight and incidence of stunting. These results are similar to previous studies conducted in Lampung Province, where the history of birth weight was not significantly associated with stunting incidence ${ }^{32}$. Birth weight has a big influence on the first 6 months of a child's life, this change decreasing with age up to 2 years. The first 6 months is the right time for the baby to be able to achieve height growth to prevent stunting $^{33}$.

Birth length is the body length measured one hour after the baby is born. Birth length is a reflection of nutrition during pregnancy. In our study, the history of birth length was not significantly associated with the incidence of stunting. This is similar to previous research where a history of birth length was not a risk factor for stunting ${ }^{34}$. History of birth length reflects the fulfillment of nutrition during pregnancy. Children whose body length is abnormal have the potential for correction if supported by the fulfillment of nutrition during postnatal care. 
Opportunities to catch up are much higher during the first 1000 days of life than after ${ }^{35}$.

Exclusive breastfeeding is breastfeeding for six months without other food additives. In our study, breastfeeding history was significantly associated with stunting incidence. This is similar to other studies where the history of breastfeeding was associated with stunting incidence ${ }^{36}$. Cohort studies in West-Iranian Azerbaijan showed that infant growth increased by 0.033 and 0.72 units per unit increase in breastfeeding duration for each weight and height ${ }^{37}$. This study shows that under optimal conditions, exclusive breastfeeding supports the growth of babies during the first 6 months or more. Body length reflects a person's diet and health in childhood. Optimal growth and development of children require adequate nutritional support and stimulation. Breastfeeding can fulfill all the basic needs of children to grow and develop, both physical-biomedical needs (foster care), love/emotional needs (compassion), as well as the need for stimulation.

The implication of this study is that prenatal factors such as anaemia and consumption of iron tablets are factors that can prevent stunting in infants. Midwives and other health workers need to provide education to pregnant women to conduct a complete antenatal clinic, especially adherence in consuming iron tablets.

In this study there were certain limitations which have to be taken into consideration. The data obtained were secondary data, taken from data that already existed and did not explore deeply into reasons. In addition, the data obtained was historical data, so it must be remembered for a long time, and not all factors that affect stunting were examined such as genetic, hormonal, infection history, parenting, and sanitation.

\section{Conclusions}

Prenatal factors such as anaemia and iron consumption during pregnancy were associated with stunting. Exclusive breastfeeding was the only postnatal factor that was associated with stunting. Infants who were given exclusive breast milk had a 3.98 times lower risk of stunting compared to babies who did not get exclusive breast milk.

\section{Acknowledgements}

We would like to thank the mothers and children and the Head of the community health centre.

\section{References}

1. Govindaraj R, Navaratne K, Cavagnero E, Rao Seshadri S. Health care in Sri Lanka:
What can the private health sector offer? South-East Asia; 2015.

2. Ministry of Health Republic of Indonesia. Indonesian Health Profile. Jakarta: Ministry of Health of the RI; 2017. 138 p.

3. MAL-ED Network Investigators. Childhood stunting in relation to the preand postnatal environment during the first 2 years of life: The MAL-ED longitudinal birth cohort study. PLoS Med 2017; 14(10): e1002408.

https://doi.org/10.1371/journal.pmed.10024 08

PMid: 29069076 PMCid: PMC5656304

4. Svefors P, Sysoev O, Ekstrom E, Persson LA, Arifeen SE, Naved RT, et al. Relative importance of prenatal and postnatal determinants of stunting: data mining approaches to the MINIMat cohort, Bangladesh. BMJ Open 2019; 9(8): 025154.

https://doi.org/10.1136/bmjopen-2018025154

PMid: 31383692 PMCid: PMC6687011

5. Kim R, Mejía-Guevara I, Corsi DJ, Aguayo VM, Subramanian SV. Relative Importance of 13 correlates of child Stunting in South Asia: Insights from nationally representative data from Afghanistan, Bangladesh, India, Nepal, and Pakistan. Social Sciences and Medicine 2017; 187:144-54.

https://doi.org/10.1016/j.socscimed 2017.0 6.017

PMid: 28686964

6. Corsi DJ, Mejía-Guevara I, Subramanian SV. Risk factors for chronic undernutrition among children in India: Estimating relative importance, population attributable risk and fractions. Social Sciences and Medicine 2016; 157:165-85.

https://doi.org/10.1016/j.socscimed.2015.1

1.014

PMid: 26625852

7. Aguayo VM, Menon P. Stop stunting: Improving child feeding, women's nutrition and household sanitation in South Asia. Maternal and Child Nutrition 2016; 12:3-11.

https://doi.org/10.1111/mcn.12283

PMid: 27187906 PMCid: PMC5084809 
8. World Health Organisation. Pregnant women must be able to access the right care at the right time, says WHO. 7 November, 2016. News release. Geneva.

9. Health Research and Development Agency. Basic Health Research 2013. National Report 2013. Jakarta; 2013.

10. Ministry of Health Republic of Indonesia. nutrition status monitoring results year 2017. 2018;

11. Ni'mah K. Factors associated with stunting in toddlers. Indonesian Nutrition Media 2015;10(1):13-9.

12. Menon KC, Ferguson EL, Thomson CD, Gray AR, Zodpey S, Saraf A, et al. Effects of anaemia at different stages of gestation on infant outcomes. Nutrition 2016; 32(1):61-5.

https://doi.org/10.1016/j.nut.2015.07.009

PMid: 26643748

13. Achadi EL, Hansell MJ, Sloan NL, Anderson MA. Women's nutritional status, iron consumption and weight gain during pregnancy in relation to neonatal weight and length in West Java, Indonesia. International Journal of Gynecology and Obstetrics 1995; 48:S103-19.

https://doi.org/10.1016/00207292(95)0232 $5-7$

14. Krishna A, Fink G, Berkman LF, Subramanian S V. Short- and long-run associations between birth weight and children's height. Economics and Human Biology 2016; 21:156-66.

https://doi.org/10.1016/j.ehb.2016.02.004

PMid: 26922363

15. Hidayatunnikmah N. Effect of socioeconomic status on the pattern of breastfeeding mother's food consumption in macronutrient components of breastmilk (carbohydrates, proteins, fats) impacting infant growth. Thesis 2018. Faculty of Public Health Universitas Airlangga.

16. Himaz R. Stunting later in childhood and outcomes as a young adult: Evidence from India. World Development 2018; 104:34457.

https://doi.org/10.1016/j.worlddev.2017.1 2.019
17. Swamilaksita PD. The efficacy of nutritional supplementation on pregnancy outcomes. Available from: https://www.researchgate.net/publication/ 320380713_The_Efficacy_of_Nutritional Suplementation_on_Pregnancy_Outcomes

18. Nisar YB, Dibley MJ, Aguayo VM. Ironfolic acid supplementation during pregnancy reduces the risk of stunting in children less than 2 years of age: A retrospective cohort study from Nepal. Nutrients 2016; 8(2):67. https://doi.org/10.3390/nu8020067 PMid: 26828515 PMCid: PMC4772031

19. Allen LH. Anaemia and iron deficiency: effects on pregnancy outcome. American Journal of Clinical Nutrition 2000; 71(5):1280S-1284S.

https://doi.org/10.1093/ajcn/71.5.1280s PMid: 10799402

20. Mumtaz Z, Shahab S, Butt N, Rab MA, DeMuynck A. Daily iron supplementation is more effective than twice weekly iron supplementation in pregnant women in Pakistan in a randomized double-blind clinical trial. Journal of Nutrition 2000; 130(11):2697-702.

https://doi.org/10.1093/jn/130.11.2697

PMid: 11053509

21. Dewi NT. The relationship between stunting in children under two years with a history of maternal anemia during pregnancy. Thesis 2018. Faculty of Public Health Universitas Airlangga.

22. Jwa SC, Fujiwara T, Yamanobe Y, Kozuka $\mathrm{K}$, Sago $\mathrm{H}$. Changes in maternal haemoglobin during pregnancy and birth outcomes. BMC Pregnancy and Childbirth 2015; 15:80. https://doi.org/10.1186/s12884-015-05161

PMid: 25884586 PMCid: PMC4389317

23. Steer PJ. Maternal haemoglobin concentration and birth weight. American Journal of Clinical Nutrition 2000; 71(5):1285S-1287S. https://doi.org/10.1093/ajen/71.5.1285s PMid: 10799403

24. Neufeld LM, Haas JD, Grajéda R, Martorell R. Changes in maternal weight from the first to second trimester of pregnancy are associated with fetal growth 
and infant length at birth. American Journal of Clinical Nutrition 2004; 79:64652.

https://doi.org/10.1093/ajcn/79.4.646

PMid: 15051610

25. Exacoustos C, Rosati P, Rizzo G, Arduini D. Ultrasound measurements of fetal limb bones. Ultrasound in Obstetrics and Gynecology 1991; 1(5):325-30. https://doi.org/10.1046/j.14690705.1991.0 1050325.x

PMid: 12797037

26. Sinsin I. Pregnancy \& Childbirth. Jakarta: Elex Media Komputido; 2008.

27. Rarastiti CN. Determinant analysis of positive deviance in pregnant women with low socioeconomic status on the weight and length of babies born in Gunung Geulis Village, Bogor Regency. Thesis 2017. Bogor Agricultural Institute.

28. Ruchayati F. Relationship between hemoglobin levels and upper arm circumference of pregnant women $3^{\text {rd }}$ trimester with length of baby born in the health center of Halmahera, Semarang. Journal of Public Health 2012; 1(2):57885.

29. Widen EM, Factor-Litvak PR, Gallagher D, Paxton A, Pierson RN, Heymsfield SB, et al. The pattern of gestational weight gain is associated with changes in maternal body composition and neonatal size HHS Public Access. Maternal and Child Health Journal 2015;19(10):2286-94. https://doi.org/10.1007/s10995-015-17475

PMid: 26179720 PMCid: PMC4575863

30. Diesel JC, Eckhardt CL, Day NL, Brooks MM, Arslanian SA, Bodnar LM. Gestational weight gain and offspring longitudinal growth in early life. Annals of Nutrition and Metabolism 2015; 67(1):4957.

https://doi.org/10.1159/000437149

PMid: 26279171 PMCid: PMC4624517

31. Delemarre-Van De Waal HA. Environmental factors influencing growth and pubertal development. Environmental Health Perspectives 1993; 101(Suppl. 2): 39-44.

https://doi.org/10.1289/ehp.93101s239

PMid: 8243404 PMCid: PMC1519930

32. Rahmadi A. Relationship between body weight and body length born with the occurrence of child stunting 12-59 months in Lampung province. Journal of Nursing 2016;XII(2):209-18.

33. Nasikhah R, Margawati A. Risk factors for stunting in toddlers age 24 - 36 months in East Semarang district. J Nutr Coll. 2012; 1(1):176-84.

34. Kusumawati E, Rahardjo S, Sari HP. Stunting risk management model for children under three years. Kesmas National Public Health Journal 2015; 9(3):249-56.

https://doi.org/10.21109/kesmas.v9i3.572

35. Crookston BT, Penny ME, Alder SC, Dickerson TT, Merrill RM, Stanford JB, et al. Children who recover from early stunting and children who are not stunted demonstrate similar levels of cognition. Journal of Nutrition 2010;140(11): 19962001.

https://doi.org/10.3945/jn.109.118927

PMid: 20844188

36. Lestari W, Margawati A, Rahfiludin Z. Risk factors for stunting in children aged 624 months in the sub-district of Penanggalan, Subulussalam, Aceh province. The Indonesian Journal of Nutrition 2014; 3(1):37-45.

37. Ghaemmaghami P, Ayatollahi SMT, Alinejad V, Sharafi Z. Growth curves and their associated weight and height factors in children from birth to 4 years old in West Azerbaijan Province, northwest Iran. Archives de Pédiatrie 2018; 25:389-93. https://doi.org/10.1016/j.arcped.2018.06.0 10

PMid: 30119913 